\title{
Ilmu Pendidikan Antropologi Dalam Difusi Kebudayaan Dan Akulturasi
}

\author{
Siti Zulfah \\ Email :2010128220005@mhs.ulm.ac.id \\ Program Studi Pendidikan IPS Fakultas Keguruan dn Ilmu Pendidikan \\ Universitas Lambung Mangkurat
}

\begin{abstract}
Abstrak
Pada ilmu antropologi dengan totalitas nyatanya wajib diberikan kesempatan buat meningkatkan metode berapresiasi, afektif secara mempunyai empati, pula bertabiat kognitif. Di mana perihal ini sebab di bisa dari pengalaman berkehidupan, secara dari subjek yang di bisa dari belajar. Dasar kebaikan dan moral dicoba secara diawasi pula dibimbing( Mutiani, 2009; Subiyakto, 2020; Subiyakto\&amp; Mutiani, 2020). Buat meningkatkan perihal ini, semacam mendekati pada reflektif partisipasi sehingga dapat mengambil watak kognitif pula simbol ciri sosial- budaya yang hendak nyatanya berubah- ubah.Sehingga dapat dikatan bahwasanya didalam sebuah masyarakat tidak ada masyarakat yang tidak memiliki suatu kebudayaan dan begitu pula bahwa kebudayaan tidakan akan pernah tercipta kalau masyarakat itu sendiri tidak ada,dikarenakan masyarakt tersebut meupakan suatu wadah dan merupakan pendukung terhadap kebudayaaan.
\end{abstract}

Kata Kunci: Kebudayaan,Difus,Akulturasi

\section{Pendahuluan}

Kebudayaan dapat didefinisikan merupakan hasil akan cita, yang merupakan karsa, dan merupakan karya yang dibuat oleh manusia sehingga hal tersebut bersifat antropologis.Untuk ruang lingkup kebudayaan sendiri meluputi akan keseluruhan dari cara bagaimana hidup yang khas untuk penekanan terhadap pengalaman yang didapat dalam aktivitas sehari hari yanag hal tersebut meliputi nilai atau idealnya dalam abstrak,norma atau suatu prinsip yang meupakan penetapan pasti terhadap sebuahaturan,serta benda-benda yang 
merupakan suatu simbul atau sebuah material.Olehnya dikarenaka hal itu maka dihasilkan oleh sebuah kolektivitas dan bukan berasal dari individu, yang mana konsep kebudayaan tersebut akhirnya mengacu aka makna-makna dalam kebersamaan. Didalam proses penciptaananya sendiri kebudayaan tidak akan dapat terlepas oleh suatu kepercayaan atau suatu keyakinan masyarakat.Adapun beberapa ajaran yang telah dipahami sekelompok masyarakat akan membentuk pola pikir yang mana kemudian akan dituangkan dalam suatu bentuk tradisi yang akan disepakati bersama-sama.

Pembelajaran dapat di miliki dari keluarga, karena tertanam hasil budaya, semacam ketentuan, metode pandang, berperilaku pada kehidupannya, pula pakar bersosial( Abbas, 2001, 2018a, 2018b; Abbas, 2018; Hardian, 2006). Pada ilmu antropologi dengan totalitas nyatanya wajib diberikan kesempatan buat meningkatkan metode berapresiasi, afektif secara mempunyai empati, pula bertabiat kognitif. Di mana perihal ini sebab di bisa dari pengalaman berkehidupan, secara dari subjek yang di bisa dari belajar. Dasar kebaikan dan moral dicoba secara diawasi pula dibimbing( Mutiani, 2009; Subiyakto, 2020; Subiyakto\&amp; Mutiani, 2020). Buat meningkatkan perihal ini, semacam mendekati pada reflektif partisipasi sehingga dapat mengambil watak kognitif pula simbol ciri sosial- budaya yang hendak nyatanya berubah- ubah. Sampai menemukan nilai yang bertabiat ilmu pengetahuan apresiatif dan reflektif. Ialah pada penemuan eksistensi orang itu sendirinya.

Sehingga dapat dikatan bahwasanya didalam sebuah masyarakat tidak ada masyarakat yang tidak memiliki suatu kebudayaan dan begitu pula bahwa kebudayaan tidakan akan pernah tercipta kalau masyarakat itu sendiri tidak ada,dikarenakan masyarakt tersebut meupakan suatu wadah dan merupakan pendukung terhadap kebudayaaan.

\section{Definisi Difusi dan Akulturasi}

Difusi ialah distribusi ataupun suatu yang bersifat tersebarnya akan budaya tersebut baik secara ilmu geografi,yang memang dapat melakukan akan perpindahan suatu bangsabangsa di permukaan bumi ini. Untuk proses dalam hal difusi dapat disebutkan penyebaran manusia. Perihal ini bisa diterangkan dengan terdapatnya proses pembiakan serta migrasimigrasi yang diiringi dengan proses menyesuaikan diri raga serta sosial budaya. Antropologi budaya ialah ilmu yang menekuni komprasi gimana warga menguasai dunia di dekat dengan metode yang berbeda. Antropologi budaya berhubungan dengan filsafat, literatur ataupun sastra, serta seni tentang sesuatu kebudayaan yang pengaruhi pengalaman seorang serta 
kelompok, membagikan donasi buat menguasai pengetahuan yang lebih lengkap, adat istiadat, serta pranata warga.

Satu wujud difusi yakni migrasi ataupun perpindahan dalam wujud penyebaran faktor akan kebudayaan tersebut juga datang dari salah satu hal yang meurpakan tempat untuk dapat ketempat lainnya di permukaan bumi, yang aman hal itu dipegang dan dibawa oleh beberapa kelompok manusia yang mana mereka telah bermigrasi. Pada penyebaran agama itu sendiri yang besar, dan untuk para pendeta dari agama Buddha, Pendeta yang merupakan seorang Nasrani serta kalangan kaum Muslim sendirihsl ini menyebarkankan bermacam faktor yang oleh karnanya kebudayaan akan sadardari mana mereka berasal, hingga dari tempatyang memangjauh sekali. Dan pertemuan baik antara kelompok yang merupakan semacam tersebut bisa atau dapat berlangsung dengan berbagai bermacam metode. Semacam ikatan symbolistic, penetration, peperangan. Ada pula bagi W. A. Haviland berkata kalau difusi merupakan penyebaran kerutinan ataupun adat yang merupakan istiadat akan bagian kebudayaan yang mana salah satu nya akan berhubungan dengan kebudayaan lainnya. Adapun hal yang merupakan proses dari difusi akan berlangsung memakai metode menyerupai ataupun imitasinya. Hal untuk meniru akan secara lebih gampang dari pada menghasilkan sendirian, paling utama tentang beberapa hal yang memang baru.

Akulturasi ialah percampuran 2 kebudayaan ataupun lebih yang silih pengaruhi. Akulturasi pula ialah sesuatu proses untuk penyesuaian terhadap diri yang cocok dengan berbagai hakikat terhadap kebudayaannya sendiri. Untuk proses tersebut menuju pada hal yang bersifat keserasian akan hal sosial yang bertabiat normal serta manusiawi. Sebutan akulturasi sendiri timbul semenjak tahun 1936 di para kalangan-kalangan para antropolog yang ada di Amerika selaku respon akan beberapa hal terhadap riset rekonstruksi berbagaia historis yang memang dianggapnya sebagai hal yang kurang lengkap sebab yang tak menggambarkan segala pergantian sosio dan kulturalnya sendiri.Akulturasi selaku pergantian kebudayaan diisyarati dengan terdapatnya ikatan antara 2 kebudayaan yang keduanya silih berikan serta menerima.Sebutan akulturasi, ataupun acculturasion ataupun culture contact, memiliki bermacam makna, antara lain bagi Suyono bahwa akulturasi ialah sesuatu proses pengiriman atau suatu bentuk transfer dari sang penerima yang berasal dari beragam faktor kebudayaan yang silih berjumpa serta berinteraksi atau meningkatkan akan suatu proses dalam interaksi atau hubungan budaya yang mana tanpa harus meninggalkan kebudayaan aslinya. Menimpa perihal tersebut Bee melansir dari novel Hadi yang berkata akulturasi ialah suatu pergantian budaya dari 2 sistem budaya yang silih berhubungan. Setelah itu Bee 
meningkatkan bahwasanya akulturasi terjalin dengan karakteristik proses pergantian yang diiringi dengan difusi, inovasi ataupun invensi yang mencerminkan suatu konsep dengan lebih menampilkan sisi kondisi kehidupan sosial budaya dari kelompok warga tersebut.Dan banyak pula yang yang lain.

\section{Konsep Difusi Kebudayaan Dan Akulturasi}

Difusi kebudayaan bagi F. Ratzel tahun ( 1844- 1904), difusi selaku pemindahan faktor sesuatu budaya kepada budaya lain. Faktor serta watak budaya tersebut digunakan buat menuntaskan permasalahan ataupun dicampurkan buat jadi komprehensif, di mana unsur akan budaya itu yang tak berkaitan baik antara yang satu terhadap hal yang lainnya ( Malinowski, 1983: 27). Sejarah akan hal itu berasal dari proses dalam penyebaran faktor budaya yang diucap proses difusi ini ialah salah satu objek riset ilmu antropologi, paling utama sub akan ilmu antropologi yang memang diakronik. Adapun proses terhadap difusi dari didalam unsur budaya ayang mana diantara lainnya yang diakibatkan dari migrasi bangsa tersebut yang mana berpindah akan dari salah satu tempat terhadap tempat lainnya di mana berupa tempat di permukaanbumi . Paling utama terhadap era prasejarah sendiri, diman kala itu kelompok dari manusia sendiri yang akan hidup selaku sosok pemburu terhadap bermigrasi yang akan menempuh suatu jarak yang memang sangatlah besar sekali, adapun unsur dari bentuk kebudayaan adalah berupa hal yang memang mereka akan membawa pula ikut sertanya penyebaran yang luas( Koentjaraningrat, 1996: 152).

Metode lain difusi kebudayaan merupakan ikatan yang diakibatkan oleh perdagangan, tetapi dengan karena yang lebih jauh daripada yang terjalin pada ikatan simbiotis. Unsurunsur kebudayaan asing di membawa oleh para orang dagang masuk kedalam kebudayaan penerima, tidak terencana serta tanpa paksaan, dengan mengambil sebutan dari ilmu antropologi, kerap diucap pacitifiquepenetration yang berarti pendapatan secara damai. Pendapatan secara damai pasti pula terdapat pada wujud ikatan yang diakibatkan oleh usaha dari penyiar agama. Jadi, datanglah para penyiar agama serta mulailah proses akulturasi yang ialah akibat dari kegiatan tersebut.

Dari dua orang yang merupakan antropolog terkemuka, ialah Melville J. Herskovits serta Bronislaw Malinowski, yang mana merka mengemukakan kalau Cultural Determinism berarti seluruh suatu hal ada didalam warga didetetapkan terdapatnya oleh suatu kebudayaan dan juga dipunyai oleh warga itu. Setelah itu, Herskovits juga berpandangan bahwa kebudayaan selaku hal atau suatu yang memang super organic dalam halnya,sebab 
kebudayaan akan turun-temurun yang mana dari generasi terhadap generasi kedepan senantiasa akan hidup terus-menerus, meski ada beberapa orang yang jadi satu kelompok atau warga tetap silih saling berubah juga yang diakibatkan oleh kematian serta kelahiran . Dengan demikian, sukar sekali buat memperoleh pembatasan penafsiran ataupun definisi yang tegas serta terinci yang mencakup seluruh suatu yang sepatutnya tercantum dalam penafsiran tersebut.

Didalam antroplogi sendiri akulturasi juga merupakan hal suatu proses dalam sosial yang mana seketika dalam suatu kebudyaan tertentu akann berhdapan sendiri dengan beberapa unsur yang berasal dari budaya orang asing.Yang mana selanjutnya akan tahapan unsur-unsur itu akan dengan mudah diterima dan diolah sehingga akan masuk ke dalam kebudyaan tersebut,akan tetapi akan tetap mempertahanakn kepribadian kebudayaan sebelumnya dan tidak menghilangkanya.Dalam mendeskripsikan proses akulturasi butuh mencermati gimana kondisi warga penerima, siapa agents of acculturationnya, saluran ataupun media apa yang dilalui, bagian tradisi mana yang terserang pengaruh, dan bagaimana reaksi masyarakat terhadap pengaruh tersebut.

\section{Proses Hubungan difusi danAkulturasi Kebudyaan}

Kajian tentang akulturasi sendiri merupakan suatu kajian yang dilakukan oleh para ahli antropologi dimasa lalu yang mana biasanya hal tersebut dilakukan dengan berdasarkan akan unsur suatu kerangka kerja yang mirip atau dengan kata lain hampir sama.Dalam hal pertama kalinya hal berupa istilah tentang akulturasi sendiri ditemukan dalam Webster's Unbridged Dictionary (1982) yang mana saat itu dikatakan "the approximation of one human race of tribe to another in culture or arts by contact " dan sampai pada tahun 1933 istilah tersebut dikenal oleh masyarakat, yang mana istilah ini mengendung artian bahwasanya akulturasi itu masih bersifat umum sekali.

Proses akulturasi telah terdapat semenjak dulu kalanya dari dalam sejarah sendiri para manusia, namun proses didalam akulturasi yang mana memiliki watak spesial baru timbul budaya Eropa Barat mulai menyebar ke Afnika, Asia Oceania, Amerika Utara, serta Amerika Latin. Berdialog tentang proses akulturasi sangat erat sekali hubungannya dengan unsurunsur yang ada dalam kebudayaan yang masuk atau budaya asing Yang memastikan pula lama ataupun tidaknya proses pencampuran sckaligus memperlihatkan diterima ataupun tidaknya budaya asing tersebut. Pada titik tertentu akulturasi jadi suatu yang terhindarkan, logika ini jadi dasar untuk pembuatan kebudayaan baru yang terangkum dalam satu zat 
bernama kebudayaan nasional Indonesia. Secara antropologis, akulturasi kebudayaan bisa terjalin apabila terdapat 2 kebudayaan warga yang keduanya mempunyai kebudayaan tertentu, kemudian silih berhubungan. Ikatan seperti itu yang menyebabkan terbentuknya penyebaran( defusi) kebudayaan.

Dalam proses penyebaran kebudayaan senantiasa bisa diperhatikan 2 proses mungkin, ialah menerima ataupun menolak untuk dapat masuknya pengaruh kebudayaan orang asing yang aman dapat mendatanginya. Dan dalam perihal untuk dapat menerima ataupun dalam bentuk menolak akan pengaruh tehadap kebudayaan-kebudayaan yang asing itu sendiri, yang amat berperan yakni pola kebudayaan( pattern of culture) dari kedua warga yang berjumpa itu. Bila terdapat pola yang sama ataupun nyaris sama, kemungkinan menerima pengaruh kebudayaan asing itu lebih besar. Apalagi kebalikannya apabila tidak terdapat kesamaan pada pola kebudayaan dari kedua budaya yang sama itu, mungkin menolak masuknya pengaruh asing itu lebih besar. Sama halnya dengan akulturasi Islam dengan budaya Jawa, yang bekerjasama antara budaya asing( Arab) dengan budaya Jawa, sehingga kedua budaya itu dapat melahirkan budaya yang luar biasa. Dari orang- orang Arab yang mengantarkan budaya Islam ke Jawa, yang masyarakatnya waktu itu masih Hindu Ibu. Pada akhirnya warga Jawa dapat menerimanya, serta budaya Islam dapat masuk pada budaya Hindu Budha dengan mengombinasikan suatu kebudayaan yang dapat diterimanya, sehingga dapat diperpadukan. Warga Jawa populer mempunyai perilaku toleransi yang tingi terhadap budaya atau pemeluk agama lain. Penemuan Anderson dalam karyanya" Vitologi dan Toleransi Orang Jawa, melaporkan orang Jawa mempunyai toleransi besar terhadap pemeluk agama- agama lain.

\section{Simpulan}

Dalam hidup, masing- masing tiap hari pendidikan antropologi tampaknya sangat membenarkan posisi seseorang dalam penduduk. Beraktifitas pendidikan sampai partisipan didik menemukan pengalaman dari proses belajar secara efektifitas pada pertumbuhan berlagak, ilmu pengetahuan, dan terampil dalam turut menujukan pendidikan yang cocok( Abbas, 2021; Mutiani, 2019, 2021). Antropologi secara fenomenologis tidak dapat berdiri sendiri, dibutuhkan disiplin ilmu, sebab fenomena sosial tidak-lah kenyataan yang berdiri sendiri tapi yang nampak ialah objek penuh dengan arti transendental.

Kehidupan warga merupakan sesuatu proses antara perorangan dalam kelompok yang didukung oleh sistem nilai yang ialah pembenaran, kelompok duit diperkuat oleh sistem pembenaran, kemampuan, penghukuman, serta penolakan. Sistem ini bisa mengayomi warga 
buat mengarah tatanan kehidupan yang sejahtera. Misalkan, lewat pertemuan ekonomi, faktor budaya asing tidak disengaja maupun dituntut ikut masuk bersama datangnya para orang dagang. Difusi bisa digolongkan jadi sebagian wujud. Bentuk- bentuk tersebut antara lain ikatan symbiotic, ikatan penetration pacifique, serta stimulus diffusion. Akibat dari difusi ataupun perpindahan nilai budaya mulai bawa pengaruh yang kenyataan. Nilai sakral sesuatu ajaran sudah beralih, demikian halnya dengan mitos serta keyakinan. Sesuatu kejujuran sudah berganti jadi manipulasi serta keserakahan.

J. W. Powel merupakan orang awal kali yang menghadirkan dan memakai kata akulturasi pada tahun 1880 semacam dilaporkan oleh US Bureau of American Ethnography. Powel mendefinisikan akulturasi selaku pergantian psikologis yang diakibatkan oleh imitasi perbandingan budaya. Akulturasi pula dimaknai selaku wujud asimilasi dalam kebudayaan, pengaruh pada sesuatu kebudayaan oleh kebudayaan lain, yang terjalin apabila pendukungpendukung dari kedua kebudayaan itu berhubungan lama.

Dalam Kamus Besar sendiri Ilmu Pengetahuan, akan disebutkan kalau akulturasi merupakan proses pencampuran 2 kebudayaan ataupun lebih sekali serta silih pengaruhi. Sebuah Candi Borobudur ialah fakta terdapatnya proses akulturasi antara kebudayaan Indonesia dengan kebudayaan India. Akulturasi merupakan proses pergantian suatu kebudayaan sebab kontak langsung dalam jangka waktu yang lama serta terus menerus dengan kebudayaan lain ataupun kebudayaan asing yang berbeda. Kebudayaan tadi dihadapkan dengan unsur- unsur kebudayaan lain yang lelet laun serta secara bertahap diterimanya jadi kebudayan sendiri tanpa melenyapkan karakter aslinya. Unsur- unsur kebudayaan kebudayaan asing itu diterima secara selektif. 27 Bagi Koentjaraningrat, akulturasi merupakan proses sosial yang mencuat apabila sesuatu kelompok warga dengan sesuatu kebudayaan tertentu dihadapkan dengan unsur- unsur dari sesuatu kebudayaan asing sedemikian rupa, sehingga unsur- unsur kebudayaan asing tersebut lelet laun diterima serta diolah ke dalam kebudayaan sendiri tanpa menimbulkan hilangnya karakter budaya itu sendiri.

\section{Daftar Pustaka}

Abbas, E. W. (2019). Building Nation Character Through Education: Proceeding International Seminar on Character Education. 
Indriyani, I. E., Syaharuddin, S., \& Jumriani, J. (2021). Social Interaction Contents on Social Studies Learning to Improve Social Skills. The Innovation of Social Studies Journal, 2(2), 93102.

Rahayu, R., Abbas, E. W., \& Jumriani, J. (2021). Social Studies Lesson Planning for Children with Intellectual Disabilities in the Pembina State Special School of South Kalimantan Province. The Kalimantan Social Studies Journal, 2(2), 160-169.

Sodiqin, A. (2008). Antropologi Al Qur'an. Yogyakarta: Arruz Media Group.

MASSA, G. D. B. ANTROPOLOGI SMA TERINTEGRASI PENGUATAN PENDIDIKAN KARAKTER

Simanjuntak, G. P. (2021). Antropologi Budaya.

Poerwanto, H. (1999). Asimilasi, Akulturasi, dan Integrasi Nasional. Jurnal Humaniora, 11(3), 29-37.

Ismail, I. (2020). Pengantar Ilmu Antropologi.

SAIQURROHMAN, A. (2019). AKULTURASI ISLAM DAN BUDAYA JAWA (Studi terhadap Seni Beladiri Asmo Jati di Desa Majan, Kecamatan Kedungwaru, Kabupaten Tulungagung).

Arifin, M., \& Khambali, K. B. M. (2016). Islam dan akulturasi budaya lokal di Aceh (studi terhadap ritual rah ulei di kuburan dalam masyarakat pidie Aceh). Jurnal IImiah Islam Futura, 15(2), 251-284. 